\title{
Pengembangan Critical Success Factor (CSF) untuk Menunjang Kinerja Pejabat Pembuat Komitmen (PPK) dalam Pembangunan Jembatan Ketapang di Banyuwangi
}

\author{
Tugiman, Bambang Syairudin \\ Jurusan Manajemen Proyek Program Studi Magister Manajemen Teknologi \\ Institut Teknologi Sepuluh Nopember, \\ e-mail:tgm.pjnwil1@gmail.com
}

\begin{abstract}
Bridge Project is a very complex work with high technology. In the project's execution there are to many problem, such as delays of implementation, overpayment and other failures. It is necessary to develop of critical success factor (CSF) to support the performance of committing officer (PPK) in the execution of it's duties and responsibilities in the implementation of the bridge project. The purpose of this study to identify the factors that are relevant to get an idea of the perception of CSF. The method used to solve complex problems in this study using analytical hierarchy process (AHP).The results of this study, the factors that affected the successful implementation of the bridge project, is the ability of the PPK in making self-estimated price (HPS) with the value $(0,038)$, the ability of consultants to assist and provide guidance to the contractor in the licensing value ratio consistency $(0,002)$ and the ability contractor in making the first project handover (PHO) value consistency ratio (0.001). The conclusion is that three factors are very affected to support the performance of committing officer (PPK) in the execution of bridge project.
\end{abstract}

Keywords: critical success factor, analytical hierarchy process, PPK, Ketapang Bridge

\section{PENDAHULUAN}

\subsection{Latar Belakang}

Pejabat Pembuat Komitmen berdasarkan Perpres RI Nomor 4 tahun 2015 tentang Perubahan keempat atas Perpres nomor 54 tahun 2010 tentang Pengadaan Barang dan Jasa Pemerintahan, yang disebut PPK adalah Pejabat yang bertanggung jawab atas pelaksanaan Barang dan Jasa. Sedangkan berdasarkan Peraturan Pemerintah Nomor 45 Tahun 2013 tentang Tata Cara Pelaksanaan Anggaran Pendapatan dan Belanja Negara, PPK adalah Pejabat yang diberi kewenangan oleh Pengguna Anggaran atau Kuasa Pengguna Anggaran untuk mengambil dan atau melakukan tindakan yang dapat mengakibatkan pengeluaran Anggaran Belanja Negara.

Berdasarkan pengertian tersebut maka PPK adalah pejabat yang berwenang untuk mengambil keputusan dan tindakan yang berakibat pada pengeluaran anggaran dan bertanggung jawab atas pelaksanaan Pengadaan Barang dan Jasa. Jika kita melihat pencairan Anggaran Belanja Negara, maka peran PPK ada pada mekanisme uang persediaan dan mekanisme langsung. Pada mekanisme Uang Panjar (UP), Peraturan Menteri Keuangan (PMK) berwenang untuk mengambil tindakan yang berakibat pada pengeluaran, sedangkan pada mekanisme LS (Lumpsum), PPK bertanggung jawab atas pelaksanaan pengadaan.

Oleh karena itu, dalam penelitian ini diharapkan akan memenuhi hasil dari analisis faktorfaktor dan sub faktor dalam keberhasilan suatu proyek. Dari faktor-faktor dan sub-subfaktor sebagai bahan kuesioner untuk disebarkan kepada responden dalam hal ini adalah tim ahli dalam konstruksi jembatan yang terdiri dari PPK, Konsultan dan Kontraktor untuk mem- 
berikan nilai pembobotan. Kemudian dilakukan proses perbandingan berpasangan antara faktorfaktor dan sub-faktor. Kemudian memasukkan hasil perbandingan berpasangan tersebut ke dalam software expert choice, Hasil kuesioner kemudian dianalisis dengan metode AHP guna menentukan prioritas CSF. AHP dipilih karena kelebihan yang dimilikinya yaitu dapat menangani struktur yang berhierarki pada faktor yang dipilih sampai pada sub faktor yang paling dalam. Hasil dari penelitian ini adalah urutan prioritas CSF yang paling berpengaruh untuk menentukan faktor penunjang kinerja PPK dalam Pembangunan Jembatan Ketapang di Banyuwangi.

\subsection{Perumusan Masalah}

Sesuai dengan latar belakang yang telah diuraikan, maka dirumuskan persoalan penelitian yang akan dikaji adalah bagaimana melakukan identifikasi faktor penjamin kesuksesan kinerja PPK dalam pelaksanaan pembangunan Jembatan Ketapang dengan metode CSF (Critical Success Factor) dan AHP (Analytical Hierarchy Process).

\subsection{Tujuan Penelitian}

Sesuai latar belakang masalah, tujuan penelitian ini adalah sebagai berikut.

1. Mengidentifikasi faktor penjamin kesuksesan kinerja PPK dalam pelaksanaan pembangunan Jembatan Ketapang.

2. Menentukan pembobotan masing-masing faktor penjamin kesuksesan kinerja PPK.

3. Mengimplementasikan Critical Success Factor (CSF) dalam pelaksanaan proyek pembangunan Jembatan Ketapang.

\subsection{Batasan Masalah}

Adapun batasan masalah yang dibahas pada penelitian ini adalah sebagai berikut.
1. Objek amatan dalam penelitian ini adalah Proyek Pembangunan Jembatan Ketapang yang dikelola oleh PPK Wilayah SitubondoKetapang-Banyuwangi di bawah pengawasan Balai Besar Pelaksanaan Jalan Nasional V Provinsi Jawa Timur.

2. Tugas dan tanggung jawab PPK yang akan dikaji dalam penelitian ini sesuai Perpres 4 Tahun 2015 Pasal 11 Ayat 1 Huruf c,d,e,h dan Pasal 11 Ayat 2 Huruf a Poin 1 dan Huruf $b$ dan mengacu pada PMK Pasal 13 Tahun 2012 tentang Pelaksanaan Anggaran.

3. Tidak ada perubahan kebijakan dari Kementerian Pekerjaan Umum dan Perumahan Rakyat (PUPR) yang terkait dengan proyek Jembatan Ketapang.

4. Tidak ada kejadian force majeure selama pelaksanaan proyek jembatan ketapang.

5. Lokasi penelitian adalah Pembangunan Jembatan Ketapang yang terletak di Banyuwangi km Surabaya $280+651$.

\section{DASAR TEORI}

\subsection{Penelitian Sebelumnya}

1. Penelitian oleh Derrich J - Z Tan and F.E Muhamad Ghazali (2011), diperoleh hasil penelitian Critical Success Factor (CSF) diperoleh dengan cara interview dengan Kontraktor Profesional Malaysia bertaraf Internasional. Dari review tersebut diperoleh 40 CSF, kemudian dikelompokkan menjadi enam kategori sebagai berikut.

Faktor manajemen proyek:

- Faktor pengadaan

- Faktor owner

- Faktor desainer

- Faktor kontraktor

- Faktor manajemen proyek 
- Faktor lingkungan bisnis (lingkungan pekerjaan)

2. Mohamad Soqib, Rizwan U., Farooqui, Sarosh H. Lodi. Hasil penelitian ini, keberhasilan proyek terdiri tujuh faktor dan subfaktor sebagai berikut.

- Faktor manajemen proyek

- Faktor yang berkaitan dengan pengadaan

- Faktor yang berkaitan dengan klien.

- Faktor yang berkaitan dengan tim desain

- Faktor yang berkaitan dengan kontraktor

- Faktor yang berkaitan dengan pimpro

- Faktor yang berkaitan dengan bisnis dan lingkungan kerja

3. Arti J. Jari, Pankaj, P. Bhangale. Dalam penelitian ini, kriteria keberhasilan proyek terdiri dari lima kriteria antara lain:

- kriteria owner

- desainer

- kontraktor

- kriteria umum

- kriteria unik

Faktor-faktor tersebut sangat bersesuaian dengan faktor-faktor yang diturunkan dari Perpres No. 4 Tahun 2015 dan PMK Pasal 13 Tahun 2012 di mana dalam peraturan tersebut, sangat spesifik dengan rencana penelitian yang akan penulis lakukan critical success factor (CSF) pejabat pembuat komitmen (PPK).

\subsection{Critical Success Factor}

Critical success factor adalah faktor atau variabel yang kritis bagi keberhasilan pelaksanaan proyek yang harus dikerjakan, di mana tanpa adanya faktor tersebut maka proyek tidak akan sukses atau berhasil dalam target maupun goal tertentu. Pada suatu proyek atau pekerjaan Critical Success Factor (CSF) ini penting sekali untuk mengidentifikasikan sebelum proyek dimulai.
Dalam wikipeda disebutkan definisi Critical Success Factors (CSF) is the form for an element that necessary for an organization or project to achieve its mission. It is a critical factor or activity required for ensuring the success of a company or an organizations. The term was unitialy used in the word of data analysis and business analysis".

"Critical success factors are those few things that must go will to ensure success for a manager or an organizations, and. That must be give special and continual attention to being about high performance. CSFs include issues vital to an organizations cured operating activities and to its future success.

Konsep faktor sukses (success factors) dibangun oleh D. Daniel dari Mc Kintey dan Company pada tahun 1961.

\section{Analytical Hierarchy Process (AHP)}

Analytic Hierarchy Process (AHP) telah diterima sebagai model pengambilan keputusan yang bersifat multikriteria, oleh orang-orang akademik maupun praktisi (Mauro, 2001). Kriteria-kriteria dibandingkan dalam bentuk perbandingan berpasangan, untuk membentuk suatu matriks preferensi, demikian pula halnya dengan alternatif. Salah satu keandalan AHP adalah dapat melakukan analisis secara simultan dan terintegrasi antara parameter yang kualitatif atau bahkan yang 'intangible' dan yang kuantitatif (Roy, B., M. Paruccini, 1994). AHP menggunakan struktur hierarki, matriks, dan algebra linier dalam memformulasikan prosedur pengambilan keputusan. Di samping itu, AHP juga menggunakan prinsip-prinsip eigenvector dan eigenvalue dalam proses pembobotan (Saaty, 1990). Menurut Saaty (1993), hierarki didefinisikan sebagai suatu representasi dari sebuah permasalahan yang kompleks dalam suatu struktur multi-level 
di mana level pertama adalah tujuan, yang diikuti level faktor, kriteria, subkriteria, dan seterusnya ke bawah hingga level terakhir dari alternatif. Dengan hierarki, suatu masalah yang kompleks dapat diuraikan ke dalam kelompok-kelompoknya yang kemudian diatur menjadi suatu bentuk hierarki sehingga permasalahan akan tampak lebih terstruktur dan sistematis (Saaty, 2010).

Tahap-tahap atau prosedur AHP (Rochmasari, 2010) meliputi hal-hal sebagai berikut.

1. Mendefinisikan struktur hierarki masalah.

2. Penilaian kriteria dan alternatif dengan melakukan perbandingan berpasangan.

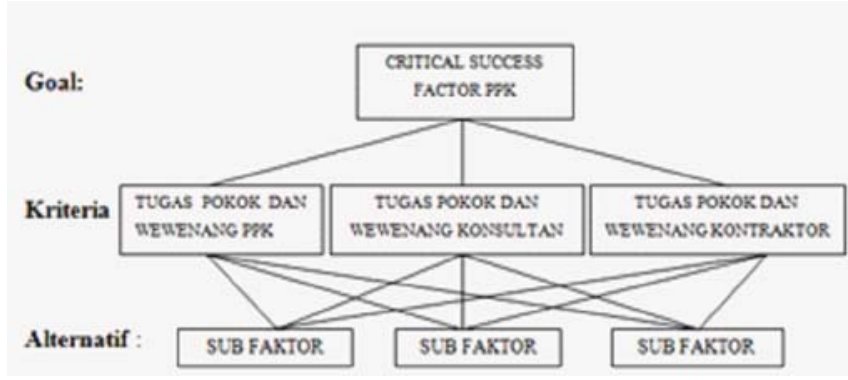

Gambar 2.1 Dekomposisi Permasalahan dalam Bentuk Model Hierarki AHP (Saaty, 1990)

Tabel 1 Skala Penilaian Perbandingan Pasangan

\begin{tabular}{|l|l|l|}
\hline $\begin{array}{c}\text { Tingkat } \\
\text { Kepentingan }\end{array}$ & \multicolumn{1}{|c|}{ Definisi } & \multicolumn{1}{c|}{ Keterangan } \\
\hline 1 & $\begin{array}{l}\text { Kedua elemen } \\
\text { sama pentingnya }\end{array}$ & $\begin{array}{l}\text { Kedua elemen se- } \\
\text { imbang sama besar } \\
\text { pada sifat tersebut }\end{array}$ \\
\hline 3 & $\begin{array}{l}\text { Elemen yang } \\
\text { satu sedikit lebih } \\
\text { penting daripada } \\
\text { elemen lainnya }\end{array}$ & $\begin{array}{l}\text { Pengalaman menya- } \\
\text { takan sedikit memi- } \\
\text { hak pada satu ele- } \\
\text { men }\end{array}$ \\
\hline 5 & $\begin{array}{l}\text { Elemen yang } \\
\text { satu lebih pen- } \\
\text { ting daripada } \\
\text { elemen lainnya }\end{array}$ & $\begin{array}{l}\text { Pengalaman me- } \\
\text { nunjukkan secara } \\
\text { kuat memihak pada } \\
\text { satu elemen }\end{array}$ \\
\hline 7 & $\begin{array}{l}\text { Satu elemen jelas } \\
\text { lebih mutlak } \\
\text { penting daripada } \\
\text { elemen lainnya }\end{array}$ & $\begin{array}{l}\text { Pengalaman menun- } \\
\text { jukkan secara kuat } \\
\text { disukai dan dido- } \\
\text { minasi satu elemen } \\
\text { yang sangat jelas } \\
\text { lebih penting }\end{array}$ \\
\hline
\end{tabular}

\begin{tabular}{|l|l|l|}
\hline 9 & $\begin{array}{l}\text { Satu elemen } \\
\text { mutlak penting } \\
\text { daripada elemen } \\
\text { lainnya }\end{array}$ & $\begin{array}{l}\text { Pengalaman me- } \\
\text { nunjukkan satu } \\
\text { elemen sangat jelas } \\
\text { lebih penting }\end{array}$ \\
\hline $2,4,6,8$ & $\begin{array}{l}\text { Nilai tengah di } \\
\text { antara dua peni- } \\
\text { laian yang ber- } \\
\text { dampingan }\end{array}$ & $\begin{array}{l}\text { Nilai ini diberikan } \\
\text { jika diperlukan } \\
\text { kompromi }\end{array}$ \\
\hline Kebalikan & $\begin{array}{l}\text { Bila elemen ke-ij } \\
\text { pada faktor i men- } \\
\text { dapat nilai x maka } \\
\text { elemen ke-ji pada } \\
\text { faktor ke-j men- } \\
\text { dapat nilai 1/x }\end{array}$ \\
\hline
\end{tabular}

Membuat matriks kriteria berpasangan, Tabel 1 skala penilaian perbandingan berpasangan membuat matriks berpasangan kriteria terhadap kriteria sebagai berikut.

1. Menjumlahkan matriks kolom.

2. Menghitung nilai elemen kolom kriteria dengan cara membagi setiap nilai elemen kolom dengan jumlah matriks kolom.

3. Menentukan prioritas kriteria jumlah baris (n kriteria).

4. Menghitung prioritas alternatif dengan membuat matriks berpasangan alternatif terhadap alternatif sebanyak jumlah kriteria.

5. Hitung konsistensi.

$\left(\lambda_{\text {maks }}\right)=\underline{O}(\mathrm{Y} / \mathrm{X})$

Keterangan:

$\mathrm{Y}=$ perkalian antara matriks perbandingan dengan bobot

$\mathrm{X}=$ hasil matriks perbandingan normalisasi

$\mathrm{n}=$ jumlah baris/atribut

6. Konsistensi Indeks (CI)

$\mathrm{CI}=\frac{\lambda_{\text {maks }}-\mathrm{n}}{\mathrm{n}-1}$

Keterangan:

$\lambda_{\text {maks }}=$ nilai konsistensi

$\mathrm{n}=$ jumlah baris

7. Consistency Ratio (CR) merupakan pernyataan yang menyatakan seberapa besar derajat 
Tugiman \& Bambang Syairudin, Pengembangan Critical Success Factor (CSF) untuk Menunjang Kinerja Pejabat Pembuat Komitmen (PPK) dalam Pembangunan Jembatan Ketapang di Banyuwangi

Inconsistency dari penetapan nilai perbandingan antar-kriteria yang telah dibuat, yaitu: $\mathrm{CR}=\mathrm{CI} / \mathrm{RI}$ (1.3)

Keterangan:

$$
\begin{aligned}
& \mathrm{CR}=\text { Consistency Ratio } \\
& \mathrm{CI}=\text { Consistency Index } \\
& \mathrm{RI}=\text { Index Random }
\end{aligned}
$$

\begin{tabular}{|c|c|}
\hline Ukuran Matriks & Nilai RI \\
\hline 1,2 & 0,00 \\
\hline 3 & 0,58 \\
\hline 4 & 0,90 \\
\hline 5 & 1,12 \\
\hline 6 & 1,24 \\
\hline 7 & 1,32 \\
\hline 8 & 1,41 \\
\hline 9 & 1,45 \\
\hline 10 & 1,49 \\
\hline 11 & 1,51 \\
\hline 12 & 1,58 \\
\hline
\end{tabular}

Tabel 2.2 Daftar Random Index (RI)

Apabila nilai $\mathrm{CR} \leq 0,10$ maka data konsisten/dapat ditoleransi tetapi bila $\mathrm{CR} \geq 0,10$ maka data tidak konsisten dan perlu dilakukan revisi. Apabila nilai $\mathrm{CR}=0$, dapat dikatakan "Perfectly Consistent”.

\section{METODE PENELITIAN}

Metodologi penelitian adalah gambaran langkah-langkah yang ditempuh dalam menjalankan penelitian dijelaskan sebagai berikut.

\subsection{Rancangan Penelitian}

a. Studi literatur dilakukan untuk mencari bahan-bahan referensi yang akandigunakan dalam penelitian ini. Dengan mengacu pada laporan justifikasi teknik, laporan rencana mutu kontrak, laporan pra-contraction meeting (PCM) mengenai pemilihan prioritas. b. Wawancara dan pengisian kuesioner dengan para pakar/ahli jembatan dalam pengambilan keputusan terhadap pemilihan prioritas ketepatan proyek jembatan Ketapang untuk mendapatkan kriteria dan alternatif dari tender tersebut.

c. Pengolahan data yang diperoleh dari hasil wawancara dan pengisian kuesioner dilakukan dengan menggunakan perangkat lunak pendukung Expert Choice.

Adapun diagram alir penelitian dapat dilihat pada diagram berikut ini.

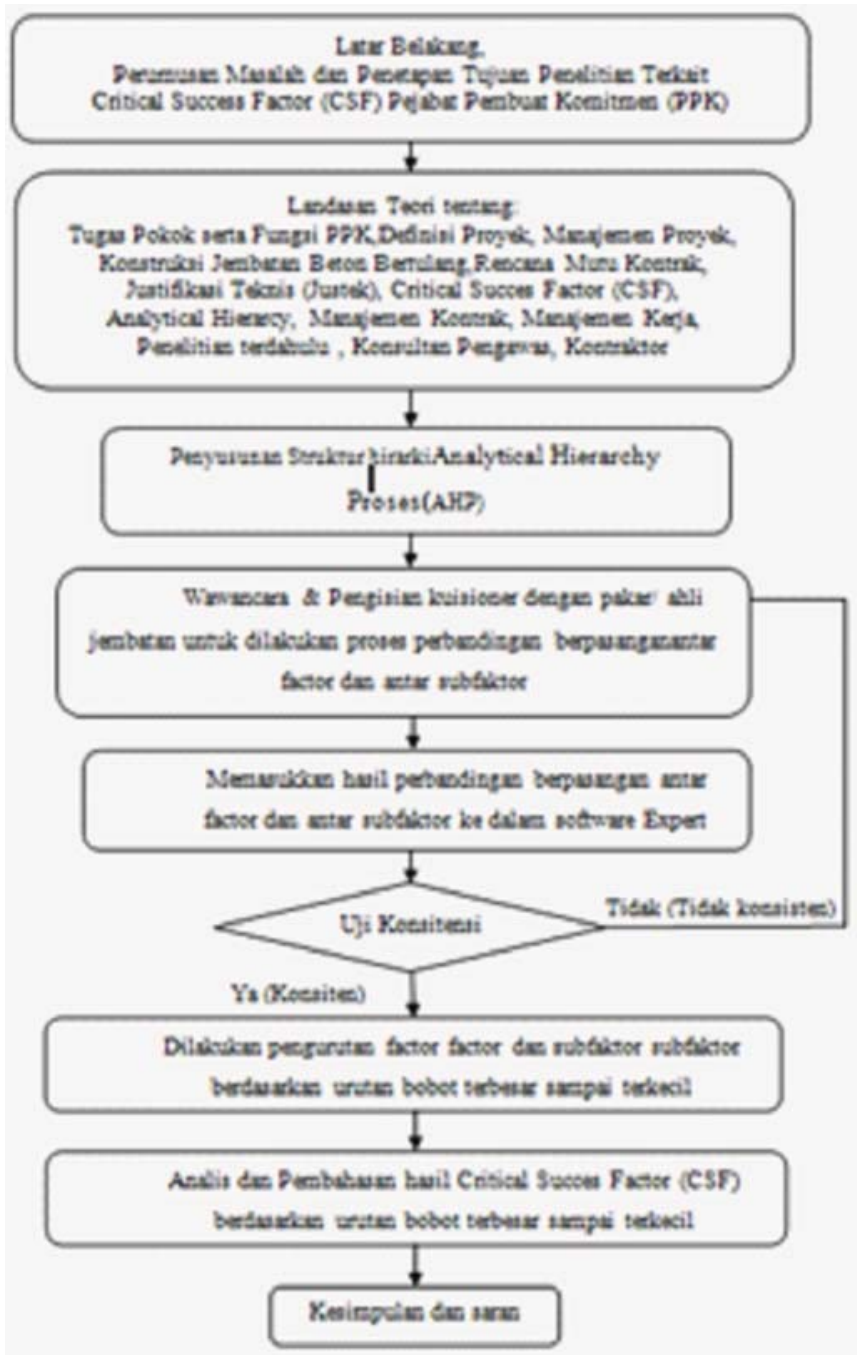

Gambar 3.1 Bagan Alir Penelitian 


\subsection{Perangkat lunak Tools yang Digunakan}

Expert Choice v.11 dipergunakan sebagai alat bantu untuk menampilkan hasil analisis dari data perbandingan antara kriteria-kriteria yaitu design, tinjauan keadaan lapangan, inventarisasi volume, mobilisasi alat, metode pembayaran, ruang lingkup pekerjaan, jadwal pekerjaan, nilai strategis proyek terhadap alternatif yang ada yaitu item-item pekerjaan dalam dokumen kontrak, survey Jembatan Ketapang dan kuantitas item pekerjaan.

\subsection{Metode Pengumpulan Data}

Sumber data primer diperoleh dari dokumen-dokumen kontrak pekerjaan proyek yang terkait dan melakukan wawancara maupun pengisian kuesioner dengan pihak-pihak pengambil keputusan dalam hal ini para pakar jembatan terhadap kriteria-kriteria yang menjadi pertimbangan keberhasilan PPK dalam melaksanakan sebuah proyek untuk mendapatkan prioritas yang utama dalam menghindari faktor kegagalan dalam mengelola sebuah proyek. Sumber data sekunder diperoleh dari data justifikasi teknik (justek).

\subsection{Proses Penentuan Prioritas Sebuah Proyek}

Di dalam keberhasilan sebuah proyek perlu diperhatikan kriteria dan alternatif dari tiaptiap proyek melalui dokumen kontrak yang dinyatakan secara tertulis maupun informasi-informasi lainnya yang tidak tertulis. Informasi-informasi yang diperoleh dari sumber tertulis disebut dengan kriteria dan laporan justifikasi teknik disebut dengan alternatif. Dari kriteria dan alternatif yang diperoleh ditentukan peringkat untuk mendapatkan kriteria dan alternatif yang terpenting terhadap tujuan pengoptimalisasian terhadap proyek-proyek dengan melibatkan PPK yang ber- sangkutan dengan pihak kontraktor beserta konsultan supervisi dalam pengambilan keputusan terhadap suatu keberhasilan proyek dan didukung dengan perangkat lunak expert choice sebagai alat bantu untuk mengambil keputusan multi-kriteria dengan menyederhanakan kompleksitas yang ada. Dari hasil pengolahan data menggunakan expert choice diperoleh prioritas sebuah proyek yang akan dipilih dengan melihat dan mempertimbangkan semua kriteria dan alternatif yang ada dan disesuaikan dengan tujuan dan kepentingan perusahaan yang hendak dicapai dari pemilihan proyek tersebut.

\subsection{Metode Analis}

Berdasarkan hasil identifikasi faktor-faktor yang berpengaruh pada proses pengambilan keputusan keberhasilan proyek dapat dibuat hierarki keputusan dari tingkat paling atas adalah tujuan, yaitu pengoptimalisasian waktu proyek sesuai dokumen kontrak pada proyek jembatan Ketapang.

\subsection{Keterkaitan Data dan Analisis Terhadap Metode AHP \& Expert Choice}

Data dalam penelitian ini terdiri dari tujuan, kriteria, dan alternatif. Adapun tujuan dari sebuah proses tender adalah pemilihan proyek dalam suatu tender. Kriteria yang diperoleh meliputi harga, yaitu besarnya nilai sebuah proyek.

1. Metode pembayaran, yaitu termin pembayaran terhadap proyek yang akan dilaksanakan.

2. Ruang lingkup pekerjaan, yaitu lingkup pekerjaan yang menjadi tanggung jawab dari PPK dan Penyedia Jasa.

3. Jadwal pekerjaan, yaitu waktu yang harus dipenuhi dalam menyelesaikan pekerjaan. 
Tugiman \& Bambang Syairudin, Pengembangan Critical Success Factor (CSF) untuk Menunjang Kinerja Pejabat Pembuat Komitmen (PPK) dalam Pembangunan Jembatan Ketapang di Banyuwangi

Dalam hal ini, AHP merupakan proses perumusan kebijakan yang powerful dan fleksibel dalam menentukan prioritas, membandingkan kriteria, alternatif dan membuat keputusan yang terbaik ketika pengambil keputusan harus mempertimbangkan aspek kuantitatif dan kualitatif. AHP mengurangi kerumitan suatu keputusan menjadi rangkaian perbandingan satusatu, kemudian menyintesis hasil perbandingan tersebut. Dengan demikian, AHP tidak hanya bermanfaat dalam pembuatan keputusan yang terbaik tetapi juga memberikan dasar yang kuat bahwa keputusan tersebut merupakan keputusan yang terbaik. Estimasi dengan menggunakan metode AHP dapat dilakukan dengan mudah dengan menggunakan perangkat lunak khusus yang disebut Expert Choice.

\section{HASIL DAN PEMBAHASAN}

\subsection{Analisis Input}

Identifikasi faktor penjamin kesuksesan kinerja PPK dalam pelaksanaan pembangunan Jembatan Ketapang ini menggunakan metode AHP dan dimaksudkan untuk membantu dalam pengambilan keputusan untuk menentukan faktor keberhasilan PPK. Dalam penentuannya ada tiga kriteria yaitu PPK, Konsultan dan Kontraktor.

a) Kriteria: PPK, Konsultan dan Kontraktor

b) Alternatif: Faktor 1 (Tugas pokok dan wewenang PPK), Faktor 2 (Tugas pokok dan wewenang Konsultan), Faktor 3 (Tugas pokok dan wewenang Kontraktor)

c) Sub alternatif: Sub Faktor 1, Sub Faktor 2, Sub Faktor 3.

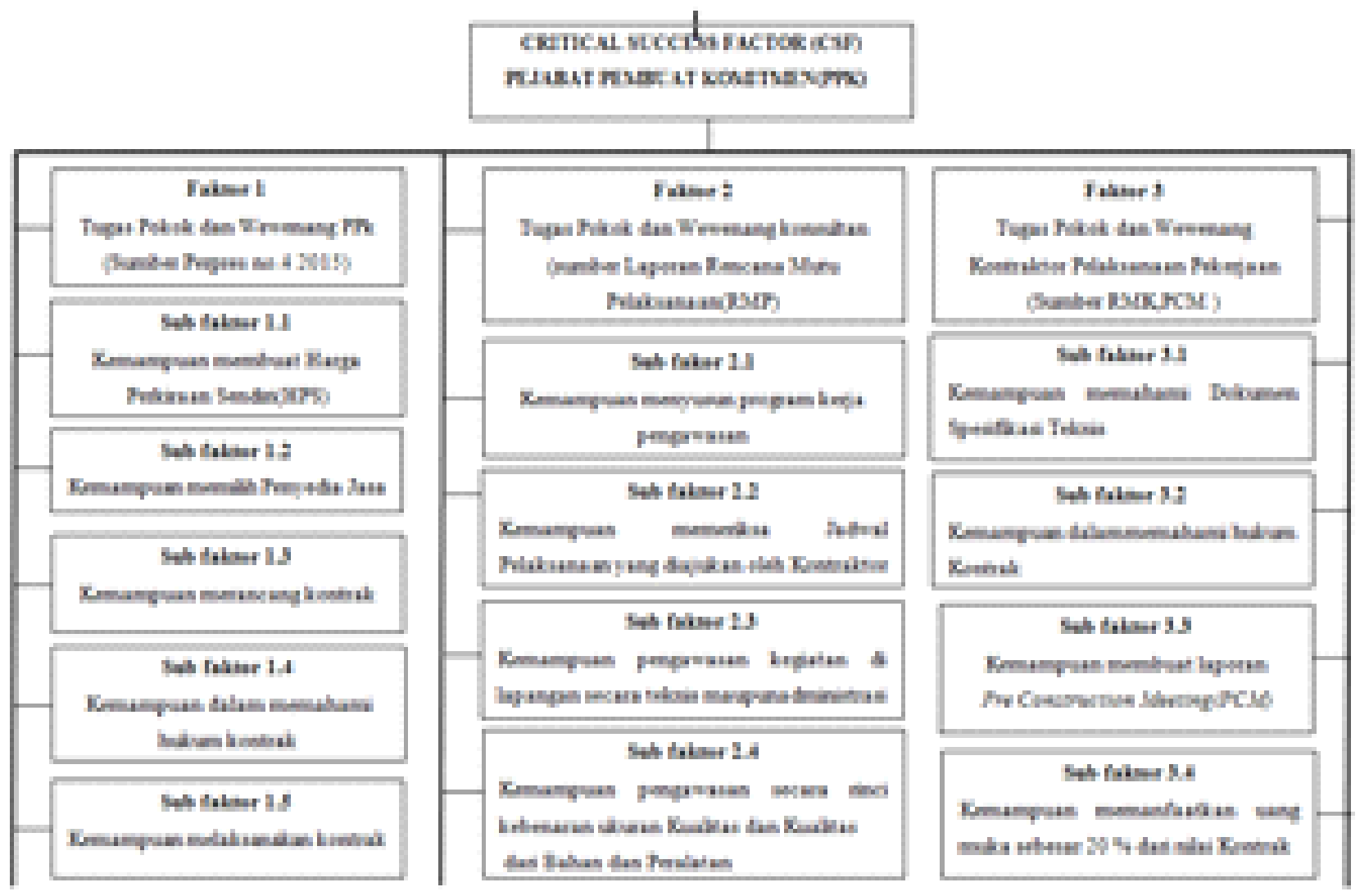



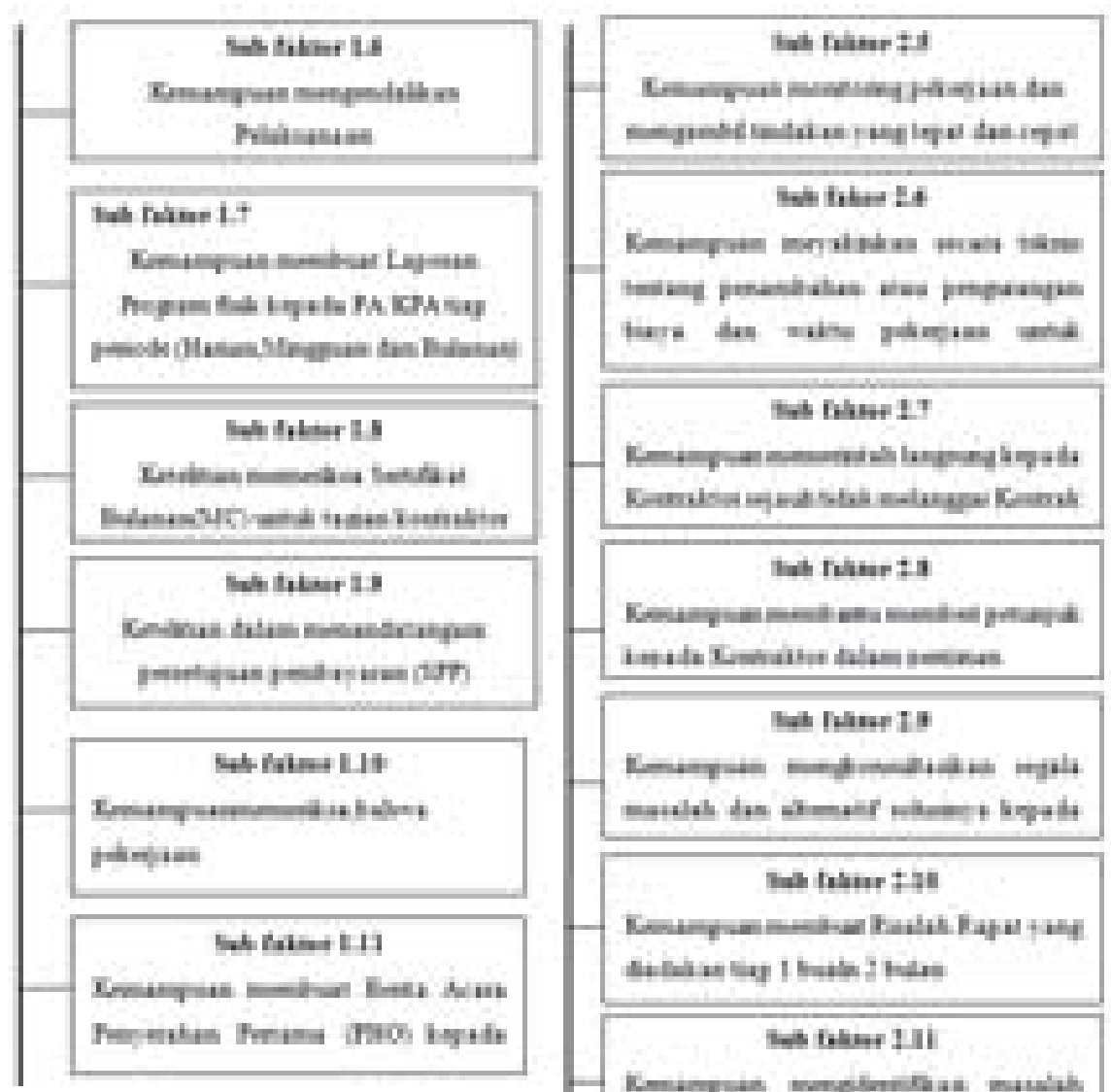

\section{fint bhar It}

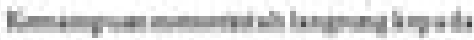

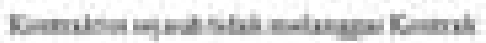

Wh form 19

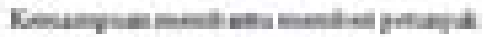

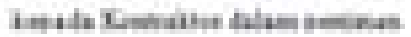

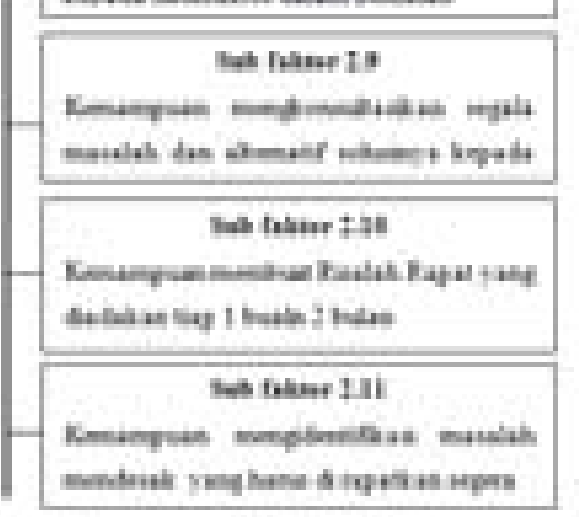

thathe th:

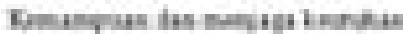
All

\begin{tabular}{|c|}
\hline tathile 14 \\
\hline 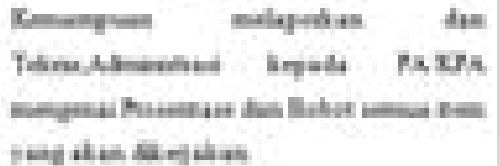 \\
\hline 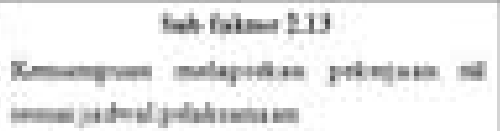 \\
\hline 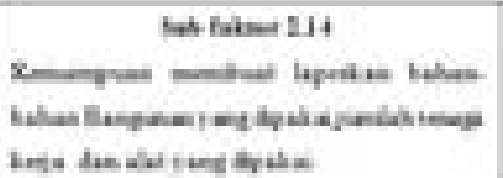 \\
\hline 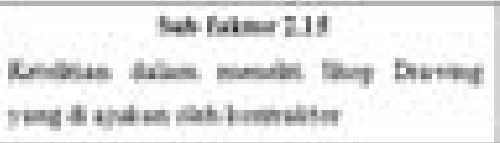 \\
\hline 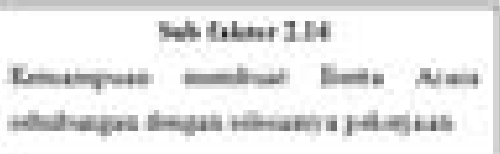 \\
\hline
\end{tabular}
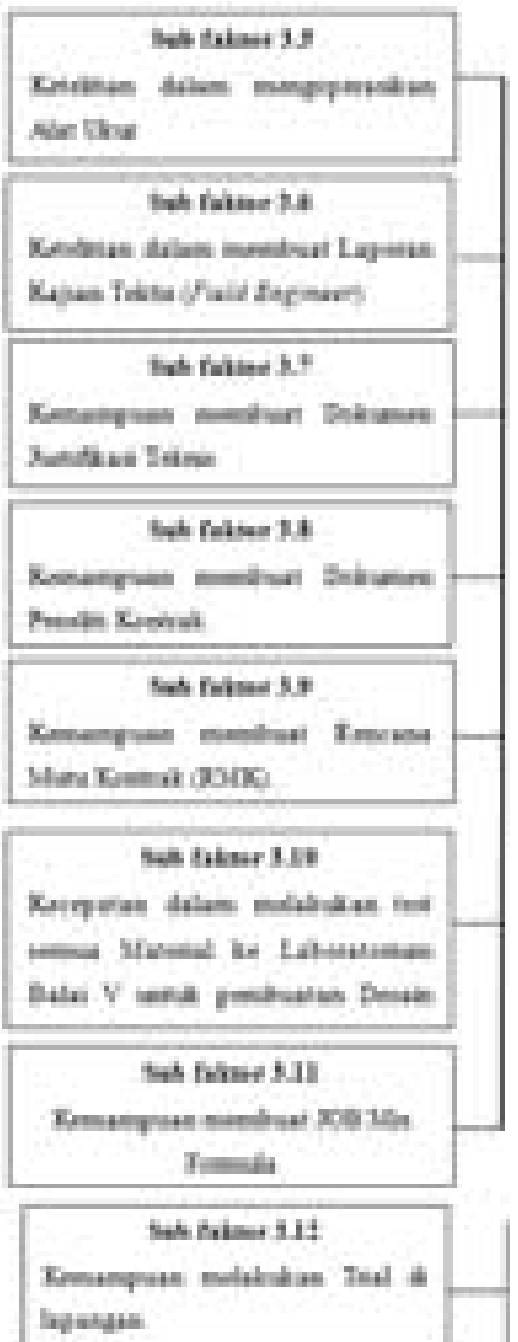

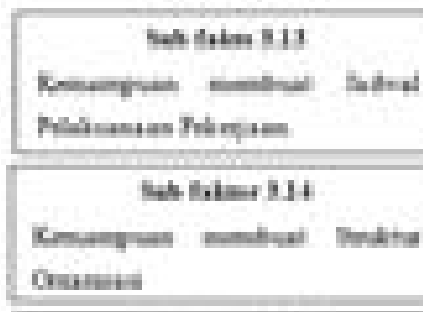

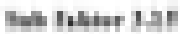

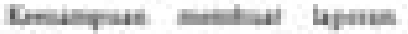

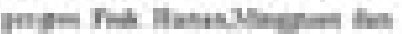
Pluais:

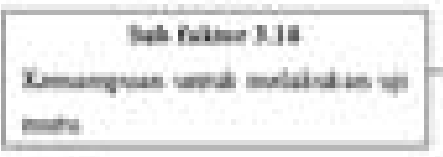

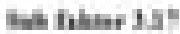

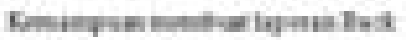

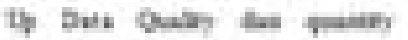

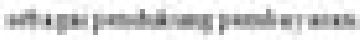


Tugiman \& Bambang Syairudin, Pengembangan Critical Success Factor (CSF) untuk Menunjang Kinerja Pejabat Pembuat Komitmen (PPK) dalam Pembangunan Jembatan Ketapang di Banyuwangi
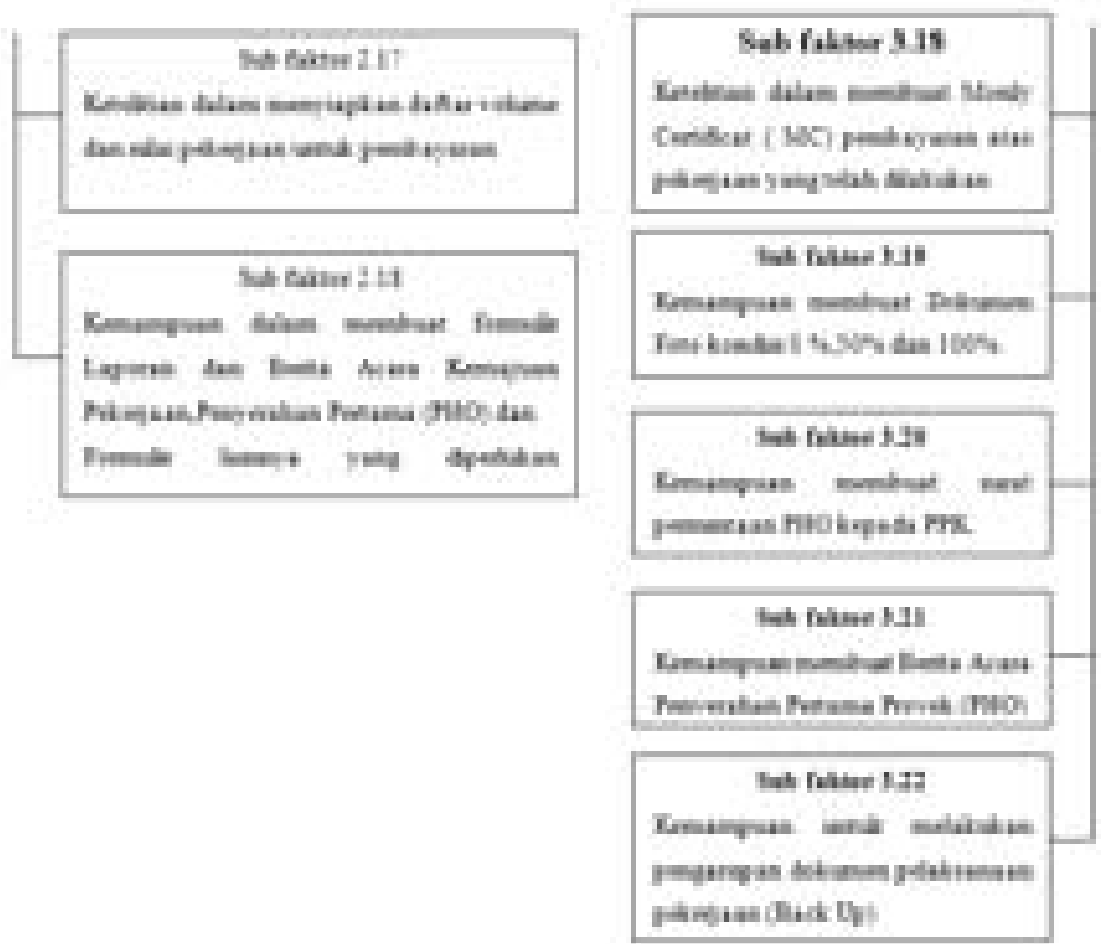

Gambar 4.1 Struktur Hierarki Critical Succes Factor dengan Metode AHP

\subsection{Bobot dan Analisis Output}

Teknik pembobotan yang digunakan untuk mengetahui tingkat kepentingan dan peranan dari tiap KPI dan perspektif adalah AHP. Keluaran yang dihasilkan dalam aplikasi ini adalah perbandingan faktor keberhasilan kinerja PPK dalam Pembangunan Jembatan Ketapang. Selain itu, dengan aplikasi ini dapat mengetahui indikator (KPI) setiap sub-faktor penting yang mempunyai nilai tertinggi dan terendah sehingga memudahkan PPK untuk memperbaiki KPI yang rendah dan mengantisipasi agar tidak terjadinya kegagalan pada proyek-proyek jembatan terdahulu.

\subsection{Implementasi Sistem}

\section{a. Halaman Utama}

Halaman ini berfungsi sebagai tampilan awal ketika menjalankan aplikasi Expert Choice Versi 11.

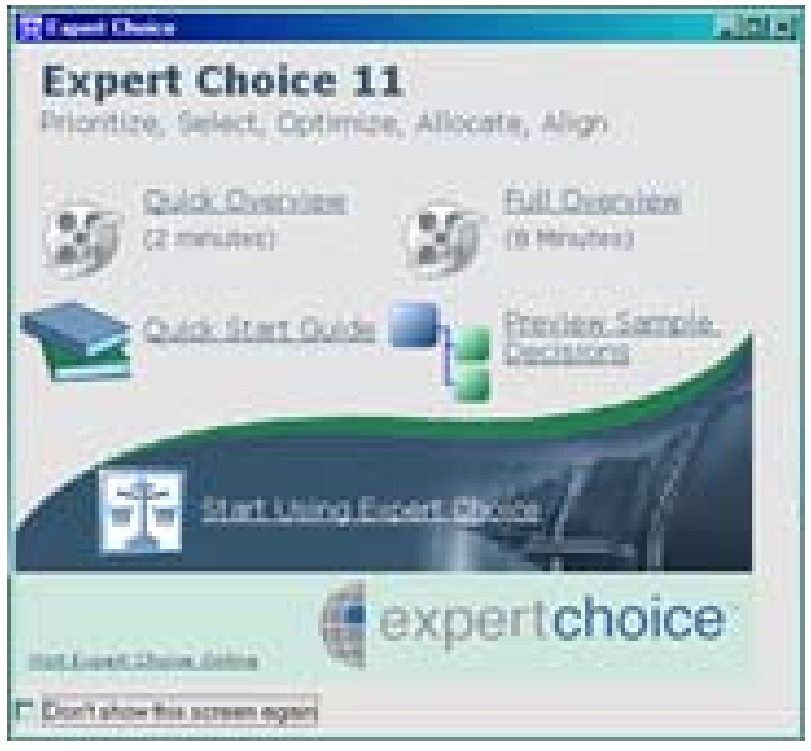

Gambar 4.2 Tampilan Pertama Kali Saat User Menjalankan Program 


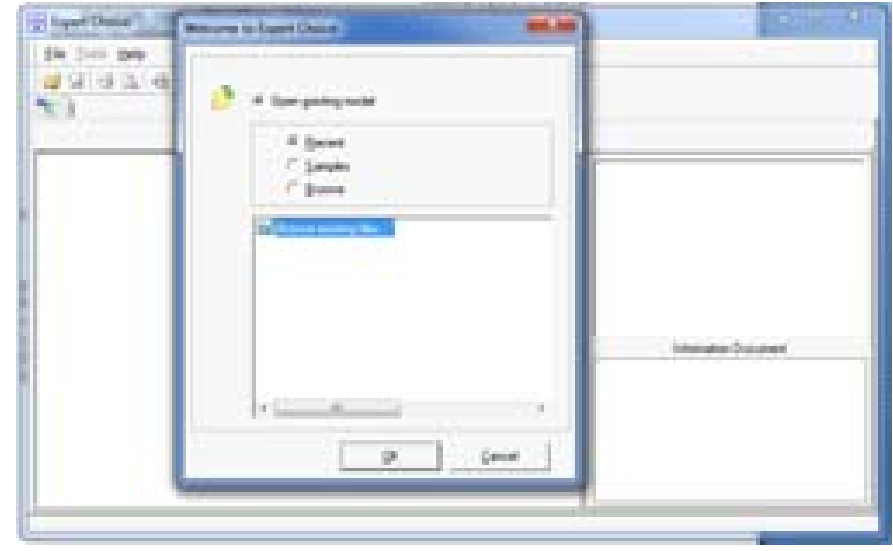

Gambar 4.3 Tampilan Saat User akan Memulai Input Data Kuesionera.

\section{b. Proses pengisian kuesioner}

Proses pengisian Kuesioner sesuai data dari hasil penyebaran masing-masing koresponden dari tim ahli BBPJN V.

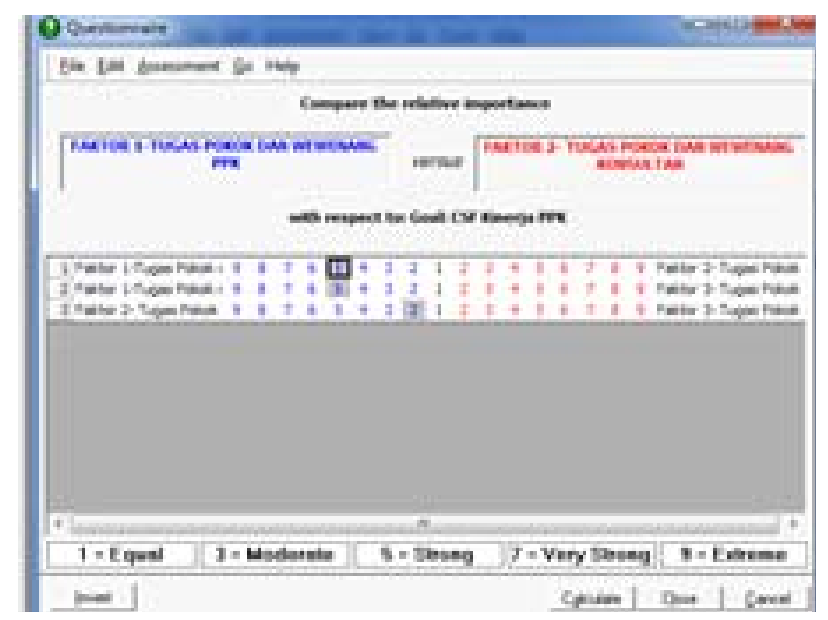

Gambar 4.4 Tampilan Saat User Memulai Input Data Kuesioner

\subsection{Analisis Hasil}

\section{a. Perhitungan Bobot Kriteria PPK}

Dari perhitungan Penginputan kuesioner AHP dapat dilakukan analisis berdasarkan hasil akhir (Skor Terbobot) tiap KPI. Di bawah ini merupakan hasil analisis faktor dari tiap-tiap kriteria.

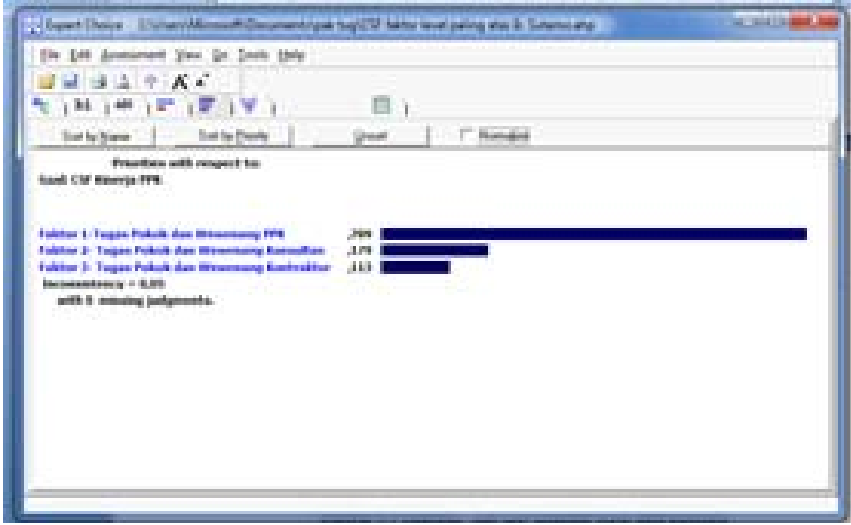

Gambar 4.4 Analisis Proses kriteria dengan CR 0.05

\section{b. Perhitungan Bobot Sub Faktor PPK}

Dari perhitungan Penginputan kuesioner AHP dapat dilakukan analisis berdasarkan hasil akhir (Skor Terbobot) tiap KPI. Di bawah ini merupakan hasil analisis Subfaktor PPK.

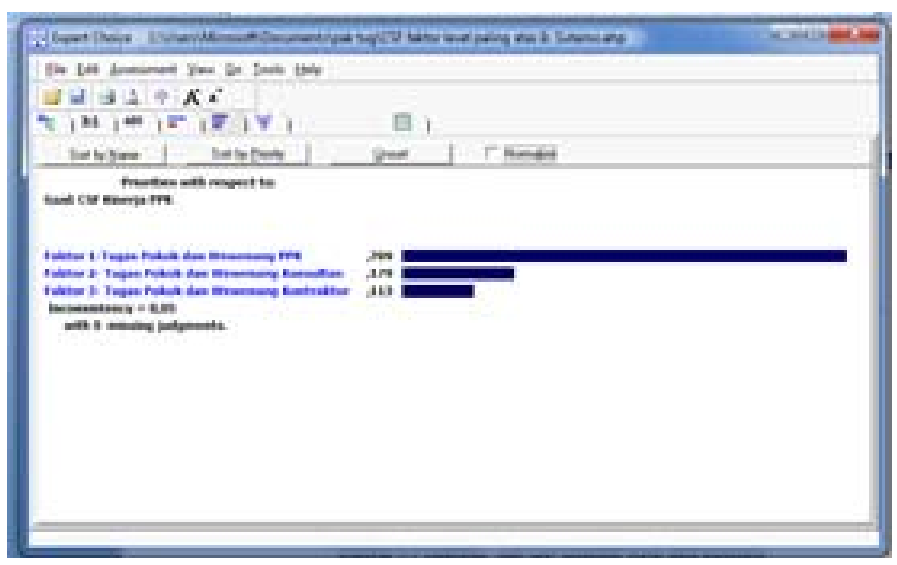

Gambar 4.5 Analisis Proses Sub-Faktor PPK dengan CR 0.09

\section{c. Perhitungan Bobot Sub-Faktor Konsultan}

Dari perhitungan Penginputan kuesioner AHP dapat dilakukan analisis berdasarkan hasil akhir (Skor Terbobot) tiap KPI. Dibawah ini merupakan analisis hasil Subfaktor dari konsultan. 
Tugiman \& Bambang Syairudin, Pengembangan Critical Success Factor (CSF) untuk Menunjang Kinerja Pejabat Pembuat Komitmen (PPK) dalam Pembangunan Jembatan Ketapang di Banyuwangi

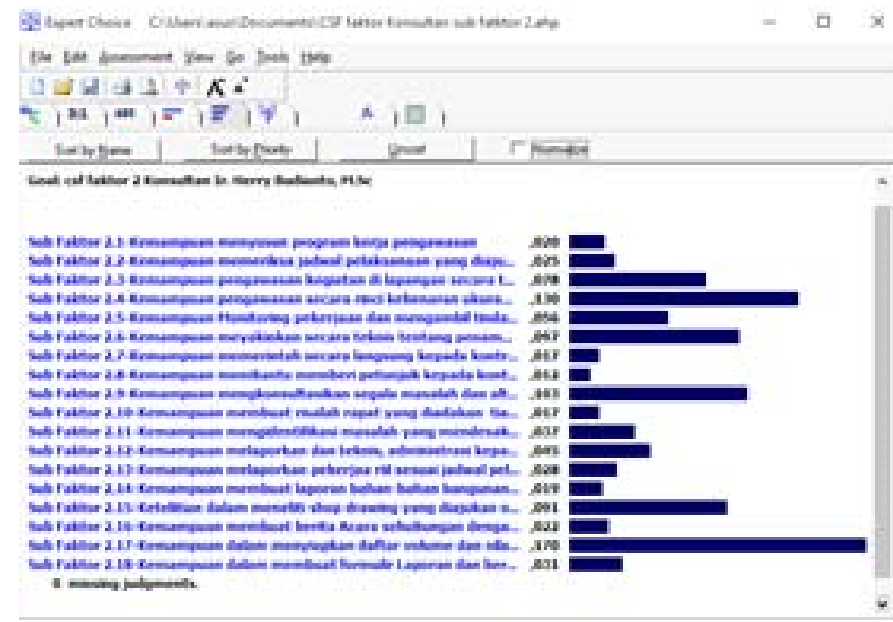

Gambar 4.6 Analisis Proses Sub-Faktor Konsultan dengan CR 0,00

\section{d. Perhitungan Bobot Sub-Faktor Kontraktor}

Dari perhitungan Penginputan kuesioner AHP dapat dilakukan analisis berdasarkan hasil akhir (Skor Terbobot) tiap KPI. Di bawah ini merupakan analisis hasil subfaktor dari kontraktor.

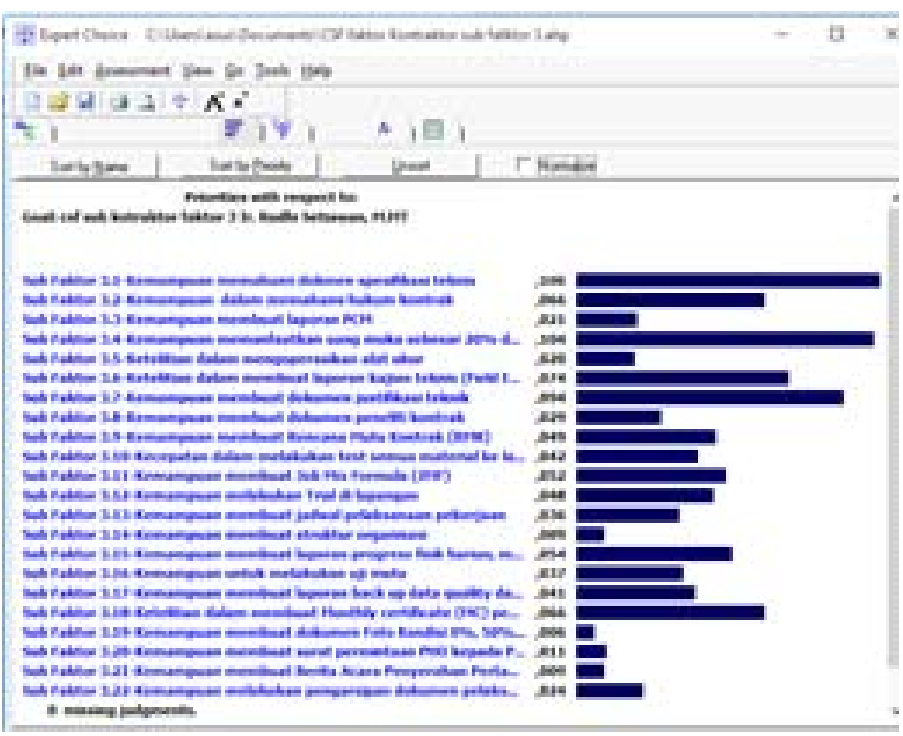

Gambar 4.7 Analisis Proses Sub-faktor Kontraktor dengan CR 0,00.

Dari hasil perhitungan Kuesioner dan AHP dapat dibuat strategi map. Berikut strategi map yang dibangun:

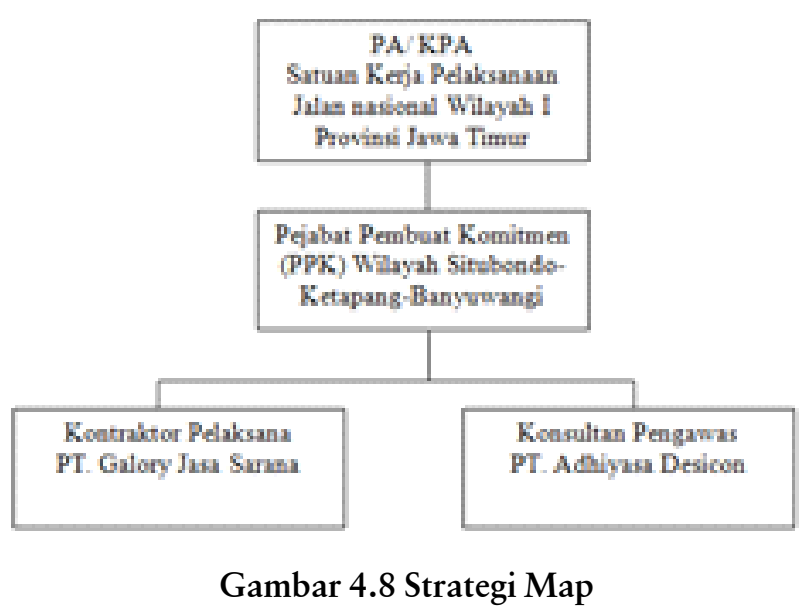

Strategi map merupakan sebuah diagram yang menunjukkan visi, misi, strategi yang diimplementasikan dalam mengukur kinerja keberhasilan dengan menggunakan KPI. Dengan menggunakan strategi map dapat di dilihat dengan jelas keterkaitan antar visi, misi organisasi dengan KPI. Berdasarkan strategi map di atas dapat dijelaskan bahwa (KPA, PPK, konsultan, kontraktor) yang mempunyai kedudukan paling tinggi dan paling berpengaruh.

\section{KESIMPULAN}

Setelah menyelesaikan Rancangan Perangkat Lunak Pengukuran penjamin kesuksesan kinerja PPK dalam pelaksanaan pembangunan Jembatan Ketapang di Banyuwangi dengan metode CSF (Critical Success Factor) dan AHP (Analytical Hierarchy Process) dapat diambil beberapa kesimpulan sebagai berikut.

Perhitungan Bobot Lokal dan Bobot Grobal

\begin{tabular}{|c|c|c|c|}
\hline No. & Faktor & $\begin{array}{l}\text { Bobot } \\
\text { Lokal }\end{array}$ & $\begin{array}{l}\text { Bobot } \\
\text { Global }\end{array}$ \\
\hline 1 & Faktor 1-Tugas Pokok dan Wewenang PPK & 0,709 & 0,709 \\
\hline 2 & $\begin{array}{l}\text { Faktor 2- Tugas Pokok dan Wewenang } \\
\text { Konsultan }\end{array}$ & 0,179 & 0,179 \\
\hline 3 & $\begin{array}{l}\text { Faktor 3- Tugas Pokok dan Wewenang } \\
\text { Kontraktor }\end{array}$ & 0,113 & 0,113 \\
\hline & Total & 1,00 & 1,00 \\
\hline
\end{tabular}




\begin{tabular}{|c|l|c|c|}
\hline No. & \multicolumn{1}{|c|}{ Sub-Faktor PPK } & $\begin{array}{l}\text { Bobot } \\
\text { Lokal }\end{array}$ & $\begin{array}{c}\text { Bobot } \\
\text { Global }\end{array}$ \\
\hline 1 & $\begin{array}{l}\text { Sub Faktor 1.1-Kemampuan membuat } \\
\text { (HPS) }\end{array}$ & 0,053 & 0,038 \\
\hline 2 & $\begin{array}{l}\text { Sub Faktor 1.2-Kemampuan memilih } \\
\text { Penyedia Jasa }\end{array}$ & 0,058 & 0,041 \\
\hline 3 & $\begin{array}{l}\text { Sub Faktor 1.3-Kemampuan merancang } \\
\text { kontrak }\end{array}$ & 0,098 & 0,069 \\
\hline 4 & $\begin{array}{l}\text { Sub Faktor 1.4-Kemampuan dalam } \\
\text { memahami hukum kontrak }\end{array}$ & 0,093 & 0,066 \\
\hline 5 & $\begin{array}{l}\text { Sub Faktor 1.5-Kemampuan } \\
\text { melaksanakan kontrak }\end{array}$ & 0,078 & 0,055 \\
\hline 6 & $\begin{array}{l}\text { Sub Faktor 1.6-Kemampuan } \\
\text { Mengendalikan Pelaksanaan }\end{array}$ & 0,100 & 0,071 \\
\hline 7 & $\begin{array}{l}\text { Sub Faktor 1.7-Kemampuan membuat } \\
\text { laporan Program fisik kepada PA/KPA } \\
\text { tiap periode(harian, Mingguan dan } \\
\text { bulanan) }\end{array}$ & 0,098 & 0,069 \\
\hline 8 & $\begin{array}{l}\text { Sub Faktor 1.8-Ketelitian memeriksa } \\
\text { sertifikat Bulanan (MC) untuk tagihan } \\
\text { kontraktor }\end{array}$ & 0,086 & 0,061 \\
\hline 9 & $\begin{array}{l}\text { Sub Faktor 1.9-Ketelitian dalam } \\
\text { menandatangani persetujuan } \\
\text { pembayaran(SPP) }\end{array}$ & 0,077 & 0,055 \\
\hline 10 & $\begin{array}{l}\text { Sub Faktor 1.10-Kemampuan memeriksa, } \\
\text { bahwa pekerjaan sudah 100\% Kepada } \\
\text { PA/KPA }\end{array}$ & $\begin{array}{l}\text { Sub Faktor 1.11-Kemampuan membuat } \\
\text { berita acara penyerahan pertama (PHO) } \\
\text { kepada PA/ KPA }\end{array}$ & 0,104 \\
\hline $\begin{array}{l}\text { Sub Faktor 1.12-Kemampuan dan } \\
\text { menjaga keutuhan dokumen }\end{array}$ & 0,074 \\
\hline 12 & 0,081 & 0,057 \\
\hline
\end{tabular}

\begin{tabular}{|c|c|c|c|}
\hline No. & Sub-Faktor Kontraktor & $\begin{array}{l}\text { Bobot } \\
\text { Lokal }\end{array}$ & $\begin{array}{l}\text { Bobot } \\
\text { Global }\end{array}$ \\
\hline 1 & $\begin{array}{l}\text { Sub Faktor 3.1-Kemampuan memahami } \\
\text { dokumen spesifikasi teknis }\end{array}$ & 0,106 & 0,012 \\
\hline 2 & $\begin{array}{l}\text { Sub Faktor 3.2-Kemampuan dalam } \\
\text { memahami hukum kontrak }\end{array}$ & 0,066 & 0,007 \\
\hline 3 & $\begin{array}{l}\text { Sub Faktor 3.3-Kemampuan membuat } \\
\text { laporan PCM }\end{array}$ & 0,021 & 0,002 \\
\hline 4 & $\begin{array}{l}\text { Sub Faktor 3.4-Kemampuan memanfaatkan } \\
\text { uang muka sebesar } 20 \% \text { dari nilai kontrak }\end{array}$ & 0,104 & 0,012 \\
\hline 5 & $\begin{array}{l}\text { Sub Faktor 3.5-Ketelitian dalam } \\
\text { mengoperasikan alat ukur }\end{array}$ & 0,020 & 0,002 \\
\hline 6 & $\begin{array}{l}\text { Sub Faktor 3.6-Ketelitian dalam membuat } \\
\text { laporan kajian teknis (Field Engineer) }\end{array}$ & 0,074 & 0,008 \\
\hline 7 & $\begin{array}{l}\text { Sub Faktor 3.7-Kemampuan membuat } \\
\text { dokumen justifikasi teknik }\end{array}$ & 0,094 & 0,011 \\
\hline 8 & $\begin{array}{l}\text { Sub Faktor 3.8-Kemampuan membuat } \\
\text { dokumen peneliti kontrak }\end{array}$ & 0,029 & 0,003 \\
\hline 9 & $\begin{array}{l}\text { Sub Faktor 3.9-Kemampuan membuat } \\
\text { Rencana Mutu Kontrak (RMK) }\end{array}$ & 0,049 & 0,006 \\
\hline 10 & $\begin{array}{l}\text { Sub Faktor 3.10-Kecepatan dalam melaku- } \\
\text { kan test semua material ke laboratorium } \\
\text { Balai V untuk pembuatan desain }\end{array}$ & 0,042 & 0,005 \\
\hline 11 & $\begin{array}{l}\text { Sub Faktor 3.11-Kemampuan membuat Job } \\
\text { Mix Formula (JMF) }\end{array}$ & 0,052 & 0,006 \\
\hline 12 & $\begin{array}{l}\text { Sub Faktor 3.12-Kemampuan melakukan } \\
\text { Trial di lapangan }\end{array}$ & 0,048 & 0,005 \\
\hline 13 & $\begin{array}{l}\text { Sub Faktor 3.13-Kemampuan membuat } \\
\text { jadwal pelaksanaan pekerjaan }\end{array}$ & 0,036 & 0,004 \\
\hline 14 & $\begin{array}{l}\text { Sub Faktor 3.14-Kemampuan membuat } \\
\text { struktur organisasi }\end{array}$ & 0,009 & 0,001 \\
\hline 15 & $\begin{array}{l}\text { Sub Faktor } 3.15 \text {-Kemampuan membuat la- } \\
\text { poran progress fisik harian, mingguan dan } \\
\text { bulanan }\end{array}$ & 0,054 & 0,006 \\
\hline 16 & $\begin{array}{l}\text { Sub Faktor 3.16-Kemampuan untuk melaku- } \\
\text { kan uji mutu }\end{array}$ & 0,037 & 0,004 \\
\hline 17 & $\begin{array}{l}\text { Sub Faktor } 3.17-\text { Kemampuan membuat } \\
\text { laporan back up data quality dan quantity } \\
\text { sebagai pendukung pembayaran }\end{array}$ & 0,041 & 0,005 \\
\hline 18 & $\begin{array}{l}\text { Sub Faktor 3.18-Ketelitian dalam membuat } \\
\text { Monthly certificate (MC) pembayaran atas } \\
\text { pekerjaan yang telah dilakukan }\end{array}$ & 0,066 & 0,007 \\
\hline 19 & $\begin{array}{l}\text { Sub Faktor 3.19-Kemampuan membuat } \\
\text { dokumen Foto Kondisi } 0 \%, 50 \% \text {, dan } 100 \%\end{array}$ & 0,006 & 0,001 \\
\hline 20 & $\begin{array}{l}\text { Sub Faktor 3.20-Kemampuan membuat surat } \\
\text { permintaan PHO kepada PPK }\end{array}$ & 0,011 & 0,001 \\
\hline 21 & $\begin{array}{l}\text { Sub Faktor 3.21-Kemampuan membuat Beri- } \\
\text { ta Acara Penyerahan Pertama Proyek (PHO) }\end{array}$ & 0,009 & 0,001 \\
\hline \multirow[t]{2}{*}{22} & $\begin{array}{l}\text { Sub Faktor 3.22-Kemampuan melakukan } \\
\text { pengarsipan dokumen pelaksanaan pekerjaan } \\
\text { (Back Up) }\end{array}$ & 0,024 & 0,003 \\
\hline & & Total & 0,113 \\
\hline
\end{tabular}

\begin{tabular}{|c|c|c|c|}
\hline 11 & $\begin{array}{l}\text { Sub Faktor 2.11-Kemampuan } \\
\text { mengidentifikasi masalah yang mendesak } \\
\text { yang harus dirapatkan segera }\end{array}$ & 0,037 & 0,007 \\
\hline 12 & $\begin{array}{l}\text { Sub Faktor 2.12-Kemampuan melaporkan } \\
\text { dan teknis, administrasi kepada PA/KPA } \\
\text { mengenai persentase dan bobot semua } \\
\text { item yang akan dikerjakan }\end{array}$ & 0,045 & 0,008 \\
\hline 13 & $\begin{array}{l}\text { Sub Faktor 2.13-Kemampuan melaporkan } \\
\text { pekerjaan riil sesuai jadwal pelaksanaan }\end{array}$ & 0,028 & 0,005 \\
\hline 14 & $\begin{array}{l}\text { Sub Faktor 2.14-Kemampuan membuat } \\
\text { laporan bahan-bahan bangunan yang } \\
\text { dipakai, jumlah tenaga kerja, dan alat yang } \\
\text { dipakai }\end{array}$ & 0,019 & 0,003 \\
\hline 15 & $\begin{array}{l}\text { Sub Faktor } 2.15 \text {-Ketelitian dalam meneliti } \\
\text { shop drawing yang diajukan oleh } \\
\text { kontraktor }\end{array}$ & 0,091 & 0,016 \\
\hline 16 & $\begin{array}{l}\text { Sub Faktor } 2.16-\text { Kemampuan membuat } \\
\text { berita Acara sehubungan dengan selesainya } \\
\text { pekerjaan }\end{array}$ & 0,022 & 0,004 \\
\hline 17 & $\begin{array}{l}\text { Sub Faktor 2.17-Kemampuan dalam } \\
\text { menyiapkan daftar volume dan nilai } \\
\text { pekerjaan untuk dibayarkan }\end{array}$ & 0,170 & 0,030 \\
\hline \multirow[t]{2}{*}{18} & $\begin{array}{l}\text { Sub Faktor 2.18-Kemampuan dalam } \\
\text { membuat formulir Laporan dan berita } \\
\text { acara kemajuan pekerjaan, penyerahan } \\
\text { pertama (PHO) dan formulir lainnya yang } \\
\text { diperlukan dalam dokumen }\end{array}$ & 0,031 & 0,006 \\
\hline & & Total & 0,179 \\
\hline
\end{tabular}

\begin{tabular}{|c|l|c|c|}
\hline No. & \multicolumn{1}{|c|}{ Sub-Faktor Konsultan } & $\begin{array}{l}\text { Bobot } \\
\text { Lokal }\end{array}$ & $\begin{array}{c}\text { Bobot } \\
\text { Global }\end{array}$ \\
\hline 1 & $\begin{array}{l}\text { Sub Faktor 2.1-Kemampuan menyusun } \\
\text { program kerja pengawasan }\end{array}$ & 0,020 & 0,004 \\
\hline 2 & $\begin{array}{l}\text { Sub Faktor 2.2-Kemampuan memeriksa jad- } \\
\text { wal pelaksanaan yang diajukan oleh kon- } \\
\text { traktor }\end{array}$ & 0,025 & 0,004 \\
\hline 3 & $\begin{array}{l}\text { Sub Faktor 2.3-Kemampuan pengawasan } \\
\text { kegiatan di lapangan secara teknis maupun } \\
\text { administrasi }\end{array}$ & 0,078 & 0,014 \\
\hline 4 & $\begin{array}{l}\text { Sub Faktor 2.4-Kemampuan pengawasan } \\
\text { secara rinci kebenaran ukuran kualitas dan } \\
\text { kualitas dari bahan dan peralatan }\end{array}$ & 0,130 & 0,023 \\
\hline 5 & $\begin{array}{l}\text { Sub Faktor 2.5-Kemampuan Monitoring } \\
\text { pekerjaan dan mengambil tindakan yang } \\
\text { tepat dan cepat }\end{array}$ & 0,056 & 0,010 \\
\hline
\end{tabular}


Tugiman \& Bambang Syairudin, Pengembangan Critical Success Factor (CSF) untuk Menunjang Kinerja Pejabat Pembuat Komitmen (PPK) dalam Pembangunan Jembatan Ketapang di Banyuwangi

\begin{tabular}{|c|l|c|c|}
\hline 6 & $\begin{array}{l}\text { Sub Faktor 2.6-Kemampuan meyakinkan } \\
\text { secara teknis tentang penambahan atau } \\
\text { pengurangan biaya dan waktu pekerjaan } \\
\text { untuk mendapatkan persetujuan dari } \\
\text { PA/KPA }\end{array}$ & 0,097 & 0,017 \\
\hline 7 & $\begin{array}{l}\text { Sub Faktor 2.7-Kemampuan memerintah } \\
\text { secara langsung kepada kontraktor sejauh } \\
\text { tidak melanggar kontrak }\end{array}$ & 0,017 & 0,003 \\
\hline 8 & $\begin{array}{l}\text { Sub Faktor 2.8-Kemampuan membantu } \\
\text { memberi petunjuk kepada kontraktor dalam } \\
\text { perizinan }\end{array}$ & 0,012 & 0,002 \\
\hline 9 & $\begin{array}{l}\text { Sub Faktor 2.9-Kemampuan mengon- } \\
\text { sultasikan segala masalah dan alternatif } \\
\text { solusinya kepada PA/KPA }\end{array}$ & 0,103 & 0,018 \\
\hline 10 & $\begin{array}{l}\text { Sub Faktor 2.10-Kemampuan membuat } \\
\text { risalah rapat yang diadakan tiap 1 bulan , } \\
\text { bulan }\end{array}$ & 0,017 & 0,003 \\
\hline
\end{tabular}

Gambar 5.1 Hasil Perhitungan Bobot Secara Global

1. Berdasarkan hasil perhitungan Analytic Hierarchy Process (AHP) menggunakan inputan kuesioner data koresponden, Kinerja sub faktor 1,2 dan Sub Faktor 3 dalam hal ini PPK, Konsultan dan Kontraktor untuk mencapai keberhasilan dalam mengantisipasi agar tidak terjadinya kegagalan pada proyek Jembatan Ketapang di Banyuwangi, PPK harus melakukan hal-hal sebagai berikut.

\begin{tabular}{|c|l|c|c|}
\hline No & Sub-Faktor keberehasilan PPK & $\begin{array}{c}\text { Bobot } \\
\text { Lokal }\end{array}$ & $\begin{array}{c}\text { Bobot } \\
\text { Global }\end{array}$ \\
\hline 1 & $\begin{array}{l}\text { Sub Faktor 1.11-Kemampuan } \\
\text { membuat berita acara } \\
\text { penyerahan pertama (PHO) } \\
\text { kepada PA/ KPA }\end{array}$ & 0,104 & 0,074 \\
\hline 2 & $\begin{array}{l}\text { Sub Faktor 1.6-Kemampuan } \\
\text { Mengendalikan Pelaksanaan }\end{array}$ & 0,1 & 0,071 \\
\hline 3 & $\begin{array}{l}\text { Sub Faktor 1.3-Kemampuan } \\
\text { merancang kontrak }\end{array}$ & 0,098 & 0,069 \\
\hline 4 & $\begin{array}{l}\text { Sub Faktor 1.7-Kemampuan } \\
\text { membuat Iaporan Program fisik } \\
\text { kepadaPA/KPA } \\
\text { periode(harian, Mingguan dan } \\
\text { bulanan) }\end{array}$ & $\begin{array}{l}\text { Sub Faktor 1.4-Kemampuan } \\
\text { dalam memahami hukum } \\
\text { kontrak 0,093 }\end{array}$ & 0,066 \\
\hline 5
\end{tabular}

Gambar 5.2 Faktor Kunci Keberhasilan PPK

\begin{tabular}{|l|l|c|c|}
\hline No & \multicolumn{1}{|c|}{ Sub-Faktor } & $\begin{array}{l}\text { Bobot } \\
\text { Lokal }\end{array}$ & $\begin{array}{c}\text { Bobot } \\
\text { Global }\end{array}$ \\
\hline 1 & $\begin{array}{l}\text { Sub Faktor 2.17-Kemampuan dalam } \\
\text { menviapkan daftar volume dan nilai } \\
\text { pekerjaan untuk dibayarkan }\end{array}$ & 0,17 & 0,030 \\
\hline 2 & $\begin{array}{l}\text { Sub Faktor 2.4-Kemampuan } \\
\text { pengawasan secara rinci kebenaran } \\
\text { ukuran kualitas dan kualitas dari } \\
\text { bahan dan peralatan }\end{array}$ & 0,13 & 0,023 \\
\hline 3 & $\begin{array}{l}\text { Sub Faktor 2.9-Kemampuan } \\
\text { mengkonsultasikan segala masalah } \\
\text { dan alternatif solusinya kepada } \\
\text { PA/KPA }\end{array}$ & 0,103 & 0,018 \\
\hline 4 & $\begin{array}{l}\text { Sub Faktor 2.6-Kemampuan } \\
\text { meyakinkan secara teknis tentang } \\
\text { penambahan atau pengurangan } \\
\text { biaya dan waktu pekerjaan untuk } \\
\text { mendapatkan persetujuan dari } \\
\text { PA/KPA }\end{array}$ & 0,097 & 0,017 \\
\hline 5 & $\begin{array}{l}\text { Sub Faktor 2.15-Ketelitian dalam } \\
\text { meneliti shop drawing vang } \\
\text { diajukan oleh kontraktor }\end{array}$ & 0,091 & 0,016 \\
\hline 6 & $\begin{array}{l}\text { Sub Faktor 2.3-Kemampuan } \\
\text { pengawasan kegiatan di lapangan } \\
\text { secara teknis maupun administrasi }\end{array}$ & 0,078 & 0,014 \\
\hline
\end{tabular}

Gambar 5.3 Faktor Kunci Keberhasilan Konsultan

\begin{tabular}{|c|l|c|c|}
\hline No & \multicolumn{1}{|c|}{ Sub-Faktor } & $\begin{array}{c}\text { Bobot } \\
\text { Lokal }\end{array}$ & $\begin{array}{c}\text { Bobot } \\
\text { Global }\end{array}$ \\
\hline 1 & $\begin{array}{l}\text { Sub Faktor 3.1-Kemampuan } \\
\text { memahami dokmen spesifikasi } \\
\text { teknis }\end{array}$ & 0,106 & 0,012 \\
\hline 2 & $\begin{array}{l}\text { Sub Faktor 3.4-Kemampuan } \\
\text { memanfaatkan uang muka sebesar } \\
20 \% \text { dari nilai kontrak }\end{array}$ & 0,104 & 0,012 \\
\hline 3 & $\begin{array}{l}\text { Sub Faktor 3.7-Kemampuan } \\
\text { membuat dokumen justifikasi } \\
\text { teknik }\end{array}$ & 0,094 & 0,011 \\
\hline
\end{tabular}

Gambar 5.4 Faktor Kunci Keberhasilan Kontraktor

2. Penentuan bobot dan target pada setiap indikator memengaruhi hasil pengukuran kinerja karena setiap bobot dan target menghasilkan tingkat kepentingan dan skor dari perhitungan kuesioner AHP sesuai dengan perhitungan bobot tertinggi sehingga dapat disimpulkan bahwa faktor keberhasilan dalam penelitian ini diambil bobot yang tertinggi.

3. Sesuai dengan hasil penelitian ini, bahwa nilai bobot faktor yang paling tinggi adalah tugas pokok dan wewenang PPK (0.709), disebabkan karena tanggung jawab PPK di- 
mulai dari perencanaan, proses pengadaan barang/jasa, pelaksanaan sampai dengan penyerahan pertama proyek (PHO) bahkan sampai dengan penyerahan akhir proyek (FHO). Sedangkan tugas pokok dan wewenang konsultan $(0,179)$. Tugas pokok dan wewenang kontraktor $(0,113)$, karena kerja konsultan dan kontraktor hanya awal pelaksanaan sampai penyerahan pertama proyek (PHO). Sedangkan sub-faktor yang sangat dominan terhadap keberhasilan pelaksanaan proyek Jembatan Ketapang adalah kemampuan pejabat pembuat komitmen (PPK) dalam membuat harga perkiraan Sendiri (HPS). Kemampuan Konsultan untuk membantu dan memberikan petunjuk kepada kontraktor dalam perizinan. Kemampuan kontraktor dalam membuat Berita Acara Penyerahan Pertama Proyek (PHO).

\section{DAFTAR PUSTAKA}

Eduardo Shimoda \& Sérgio França. 2014. Critical Success Factor in Project Management Study of an Energy Company in Brazil. USA: Global Journals Inc.

Derrick J-Z Tan and F.E. Mohamed Ghazali. 2011. Critical Success Factor for Malaysian Contractor Project using AHP. Singapore: EPPM.

Muhammad Saqib, Rizwan U. Farooqui. 2008. Assessment of Critical Success Factors for Construction Projects in Pakistan.
ICCIDC-I: NED University of Engineering.

David Scott, Albert P.C. \& Ada P.L.Chan. 2004. Factors Affecting the Success of A Construction Project. Technical Notes: Journal.

Gunawan, Moch. Afifudi, Ibnu abbas majid. 2014. Critical Success Factor Pelaksanaan Proyek Konstruksi Jalan dan Jembatan di Kabupaten Pidie Jaya, Banda Aceh. Jurnal Teknik Sipil Pasca Sarjana Universitas Syiah Kuala.

Perpres RI Nomor 4 Tahun 2015 tentang: Perubahan Keempat atas Perpres Nomor 54 Tahun 2010 tentang Pengadaan Barang dan Jasa Pemerintah.

Perpres RI nomor 45 tahun 2013 tentang: Tata Cara Pelaksanaan Anggaran Pendapatan dan Belanja Negara.

Laporan Pre Construction Meeting (PCM), Paket Pembangunan Jembatan Ketapang Tahun Anggaran 20016.

Laporan Rencana Mutu Kontrak (RMK), Penyedia Jasa PT Galory Jasa Sarana Paket Pembangunan Jembatan Ketapang tahun Anggaran 2016.

Laporan Justifikasi Teknik, Paket Pembangunan Jembatan Ketapang Tahun Anggaran 2016. Laporan Rencana Mutu Pelaksanaan (RMP). Konsultan Pengawasan PT Adhiyasa Desicon.

A Guide to the Project Management Body of Knowledge (PMBOK Guide). Fifth Edition. 